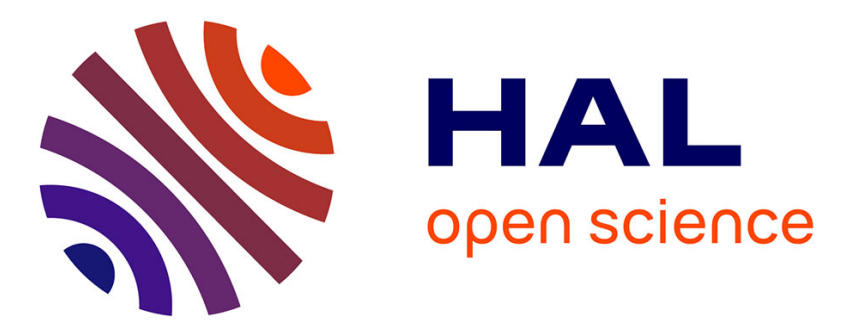

\title{
Structural phase diagrams and isomerism inflexible honeycomb-like 2D hydrogen bonded solid solutions
}

Bo-Wen Hu, Sylvie Ferlay, Nathalie Gruber-Kyritsakas, Mir Wais Hosseini

\section{To cite this version:}

Bo-Wen Hu, Sylvie Ferlay, Nathalie Gruber-Kyritsakas, Mir Wais Hosseini. Structural phase diagrams and isomerism inflexible honeycomb-like 2D hydrogen bonded solid solutions. CrystEngComm, 2018, 20 (13), pp.1853-1861. 10.1039/C8CE00023A . hal-02300927

\section{HAL Id: hal-02300927 \\ https://hal.science/hal-02300927}

Submitted on 25 Nov 2020

HAL is a multi-disciplinary open access archive for the deposit and dissemination of scientific research documents, whether they are published or not. The documents may come from teaching and research institutions in France or abroad, or from public or private research centers.
L'archive ouverte pluridisciplinaire HAL, est destinée au dépôt et à la diffusion de documents scientifiques de niveau recherche, publiés ou non, émanant des établissements d'enseignement et de recherche français ou étrangers, des laboratoires publics ou privés. 


\title{
Journal Name
}

\section{ARTICLE}

\section{Structural phase diagram and isomery in flexible honeycomb-like 2D hydrogen bonded solid solutions}

Received 00th January 20xx Accepted 00th January 20xx

\author{
Bo-Wen Hu, ${ }^{a, b}$ Sylvie Ferlay, ${ }^{a^{*}}$ Nathalie Gruber-Kyritsakas ${ }^{a}$ and Mir Wais Hosseini ${ }^{a}$
}

Solid solution of Hydrogen bonded networks of formula $\left(\left(1-2 \mathrm{H}^{+}\right)_{3 \mathrm{x}}\left(2-2 \mathrm{H}^{+}\right)_{3(1-\mathrm{x})}\left(\left[\mathrm{Fe}(\mathrm{CN})_{6}\right]^{3-}{ }_{2}\right)\right)$. $\mathrm{nH}_{2} \mathrm{O}$, where $\left(1-2 \mathrm{H}^{+}\right)$and $\left(1-2 \mathrm{H}^{+}\right)$are bisamidinium $H$ bond donor entities, have been synthetized and structurally analysed. The $H$ bonded systems display a honeycomb-like structure, and depending on the $x$ value, three different pavages of the $(6,3)$ system are observed, leading to three different phases. The precise location of the $\mathrm{H}$ bond donor cations $\left(2-2 \mathrm{H}^{+}\right)$have been performed, evidencing $H$ bonding between adjacent cations. Thermal properties of the solid solutions have been performed.

\section{Introduction}

A crystalline solid solution is a mixture of at least two crystalline pure phases that coexist as a new crystalline phase. Kitaigorodsky ${ }^{1}$, through his pioneering work, showed that in mixed crystals the relationship between composition and structure property is often described by Vegard's law. ${ }^{2}$ When the components of the solid solution are molecular entities, these systems can be called molecular alloys. ${ }^{3}$ Engineering molecular crystals with multicomponents that form solid solution or molecular alloys is a hot topic in material science because of their new or superior functionalities such as optics, ${ }^{4}$ ferroelectric, ${ }^{5}$ catalysis ${ }^{6}$ or magnetism. ${ }^{7}$ In order to enhance the collective properties of such entities, structural property correlation is a crucial issue. The structure prediction including the recognition pattern between the molecular components, and the crystal packing in the crystal, is still an open topic. ${ }^{8}$ Substantial progress has been made recently in crystal structure prediction, however obtaining crystals with desired space group symmetry and controlled arrangement of supramolecular motifs still remains a great challenge. ${ }^{9}$

Through the molecular tectonics ${ }^{10}$ approach, the design and synthesis of supramolecular architectures was achieved. ${ }^{11} \mathrm{We}$ demonstrated the building of large families of components

\footnotetext{
a. Molecular Tectonics Laboratory, Université de Strasbourg, CNRS, CMC UMR 7140, F-67000 Strasbourg, France E-mail:ferlay@unistra.fr, hosseini@unistra.fr

b. MIIT Key Laboratory of Critical Materials Technology for New Energy Conversion and Storage, School of Chemistry and Chemical Engineering, Harbin Institute of Technology, Harbin 150001, China.

† Footnotes relating to the title and/or authors should appear here.

Electronic Supplementary Information (ESI) available: [details of any supplementary information available should be included here]. See DOI: $10.1039 / x 0 \times x 00000 x$
}

held by hydrogen bonds and rationalised their recognition pattern, and thus the formed molecular networks. ${ }^{12,} 13$

While the majority of reported molecular solid solutions are inorganic in nature, ${ }^{14}$ there are few examples of organic solid solutions in the crystalline state. ${ }^{15}$ For the formation of solid solution, hydrogen bonding 16 but also charge-assisted $\mathrm{H}$ bonding ${ }^{17}$ is one of the very important used strategies, due to their flexibility and reliability. ${ }^{18}$

The co-crystallization of polymorphic hydrogen bonded networks is a unique opportunity to explore the different connectivity patterns that a molecular system may adopt. The influence of the connectivity pattern on the collective properties of a network is also an interesting illustration of the structure-property correlations. In the field of mixed crystals, it has been shown how non-stoichiometric mixtures can afford precise tuning of the optical properties, for example. ${ }^{19}$ Concerning hydrogen bonded systems, the solid solution maybe a tool for controlling lattice metrics, magnetic properties, absorption spectrum, polymorphism, and sorption properties..$^{20}$ In the case of hydrogen bonded systems, we have also shown that the porosity may be tuned by controlling the ratio of cations in solid solutions. ${ }^{13 d}$

In this context, we have investigated different possible connectivity patterns in a series of solid solutions of $\mathrm{H}$ bonded systems, presenting different crystallographic phases. The solid solutions are based on the mixture of organic ligand that will lead to distinct crystallographic phases.

We have already shown that bisamidinium dications (1$2 \mathrm{H}^{+}$) and $\left(2-2 \mathrm{H}^{+}\right)$(Figure 1 ) have been well designed as $\mathrm{H}$-bond donors, and when combined with carboxylates or cyanometallates it leads to 1D or 2D charge-assisted networks (fig. 1). ${ }^{12}$ For example, their associations with octahedral $\left[\mathrm{M}(\mathrm{CN})_{6}\right]^{3-}(\mathrm{M}=\mathrm{Fe}, \mathrm{Co}$ or $\mathrm{Cr}$ ) cyanometallates leads to porous 
$\mathrm{H}$ bonded isostructural crystals with a 2D dimentionality. ${ }^{12,13 a, b, 21}$

More precisely, when bisamidinium dications $\left(1-2 \mathrm{H}^{+}\right)$and $\left(2-2 \mathrm{H}^{+}\right)$(figure 1, top) are combined with $\left[\mathrm{M}(\mathrm{CN})_{6}\right]^{3-}, 2 \mathrm{D}$ honeycomb-like networks $((6,3)$ networks) result, presenting the same connectivity pattern between anions and cations. (1$\left.2 \mathrm{H}^{+}\right)_{3}\left(\left[\mathrm{Cr}(\mathrm{CN})_{6}\right]^{3-}{ }_{2}\right)$ and $\left(2-2 \mathrm{H}^{+}\right)_{3}\left(\left[\mathrm{M}(\mathrm{CN})_{6}\right]^{3-}{ }_{2}\right)(\mathrm{M}=\mathrm{Fe}, \mathrm{Co}$, and $\mathrm{Cr})$, crystallise in the $P 2_{1} / \mathrm{n}$ space group, whereas (1$\left.2 \mathrm{H}^{+}\right)_{3}\left(\left[\mathrm{Fe}(\mathrm{CN})_{6}\right]^{3-}{ }_{2}\right)$ and $\left(1-2 \mathrm{H}^{+}\right)_{3}\left(\left[\mathrm{Co}(\mathrm{CN})_{6}\right]^{3-}{ }_{2}\right)$ crystallise in the $\mathrm{P} \overline{1}$ space group. ${ }^{13 a, b, 21}$ As shown by their crystallographic parameters presented in table $1,\left(1-2 \mathrm{H}^{+}\right)_{3}\left(\left[\mathrm{Fe}(\mathrm{CN})_{6}\right]^{3-}{ }_{2}\right) .7 \mathrm{H}_{2} \mathrm{O}$ (compound 3) and $\left(2-2 \mathrm{H}^{+}\right)_{3}\left(\left[\mathrm{Fe}(\mathrm{CN})_{6}\right]^{3-}{ }_{2}\right) .8 \mathrm{H}_{2} \mathrm{O}$ (compound 9) are not isostructural.

Table 1: Crystallographic data for $\left(\mathbf{1}-2 \mathrm{H}^{+}\right)_{3}\left(\left[\mathrm{Fe}(\mathrm{CN})_{6}\right]^{3-}{ }_{2}\right)(\mathbf{3})$ and (2$\left.2 \mathrm{H}^{+}\right)_{3}\left(\left[\mathrm{Fe}(\mathrm{CN})_{6}\right]^{3-}{ }_{2}\right)(9)$ recorded at $173 \mathrm{~K} .{ }^{21}$

\begin{tabular}{|c|c|c|}
\hline & $\left(1-2 \mathrm{H}^{+}\right)_{3}\left(\left[\mathrm{Fe}(\mathrm{CN})_{6}\right]^{3-}{ }_{2}\right) \cdot 7 \mathrm{H}_{2} \mathrm{O}(\mathbf{3})$ & $\left(2-2 \mathrm{H}^{+}\right)_{3}\left(\left[\mathrm{Fe}(\mathrm{CN})_{6}\right]^{3-}{ }_{2}\right) \cdot 8 \mathrm{H}_{2} \mathrm{O}(\mathbf{9})$ \\
\hline $\begin{array}{l}\text { Space } \\
\text { Group }\end{array}$ & $\begin{array}{c}\mathrm{P} \overline{1} \\
\text { Phase A }\end{array}$ & $\begin{array}{c}\mathrm{P} 2_{1} / \mathrm{n} \\
\text { Phase } \mathrm{C}\end{array}$ \\
\hline $\mathrm{a}(\AA ̊)$ & $7.0949(3)$ & $7.0978(5)$ \\
\hline$b(\AA)$ & $12.3765(5)$ & $22.2254(16)$ \\
\hline$c(\AA)$ & $17.9534(7)$ & $20.6357(12)$ \\
\hline$\alpha\left(^{\circ}\right)$ & $83.580(2)$ & 90 \\
\hline$\beta\left(^{\circ}\right)$ & $87.6101(10)$ & $92.363(3)$ \\
\hline$\gamma\left({ }^{\circ}\right)$ & $83.9340(10)$ & 90 \\
\hline$V\left(\AA^{3}\right)$ & $1557.12(11)$ & $3252.5(4)$ \\
\hline
\end{tabular}

Concerning the crystallographic parameters, compounds 3 and 9 display quite different cell parameters and a similar recognition pattern between anions and cations (leading to a $(6,3)$ network). The recognition of $\left[\mathrm{Fe}(\mathrm{CN})_{6}\right]^{3-}$ with $\left(\mathbf{X}-2 \mathrm{H}^{+}\right)$, with a 2/3 stoechiometry, leads to distorted hexagons, through the connections of anionic $\left(\left[\mathrm{Fe}(\mathrm{CN})_{6}\right]^{3-} /\left(\mathbf{X}-2 \mathrm{H}^{+}\right)\right) 1 \mathrm{D}$ arrays by $(\mathbf{X}-$ $\left.2 \mathrm{H}^{+}\right)$cations. In the case of $\left(2-2 \mathrm{H}^{+}\right)$, a shift of the connecting bisamidinium cations $\left(2-2 \mathrm{H}^{+}\right)$between the $1 \mathrm{D}$ anionic arrays is observed, enabling the switching of crystallographic space groups from $\mathrm{P} \overline{1}\left(\mathbf{1}-2 \mathrm{H}^{+}, \mathbf{3}\right)$ to $P 2_{1} / \mathrm{n}\left(\mathbf{2}-2 \mathrm{H}^{+}, \mathbf{9}\right)$, as shown in figure $1 . .^{21}$ The driving force of this feature is the $\mathrm{HO} \cdots \mathrm{OH}$ interactions, of two hydroxyl groups belonging to two adjacent $\left(2-2 \mathrm{H}^{+}\right)$cations located on each side of the $\left[\mathrm{Fe}(\mathrm{CN})_{6}\right]^{3-}$ anions, with $\mathrm{O}-\mathrm{O}$ distance of $2.828(5) \AA$, in compound 9 , whereas this interaction is of course not observed in compound $\mathbf{3}$. In addition, other types of $\mathrm{H}$-bonds, such as $\mathrm{O}_{2} \mathrm{H} \cdots \mathrm{N} \equiv \mathrm{C}, \mathrm{O}_{2} \mathrm{H} \cdots \mathrm{OH}$, $\mathrm{H}_{2} \mathrm{O} \cdots \mathrm{HO}-\mathrm{C}, \mathrm{H}_{2} \mathrm{O} \cdots \mathrm{H}_{2} \mathrm{O}$, further stabilize this disposition, as shown in figure $1 .{ }^{21}$

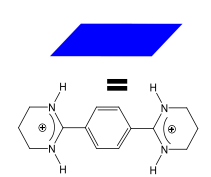

$\left(1 \cdot 2 \mathrm{H}^{+}\right)$

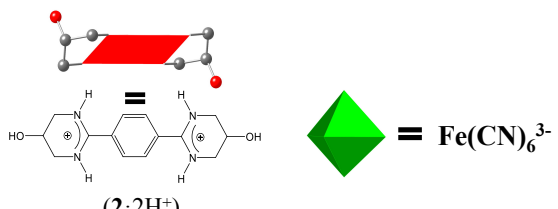

$\left(2 \cdot 2 \mathrm{H}^{+}\right)$

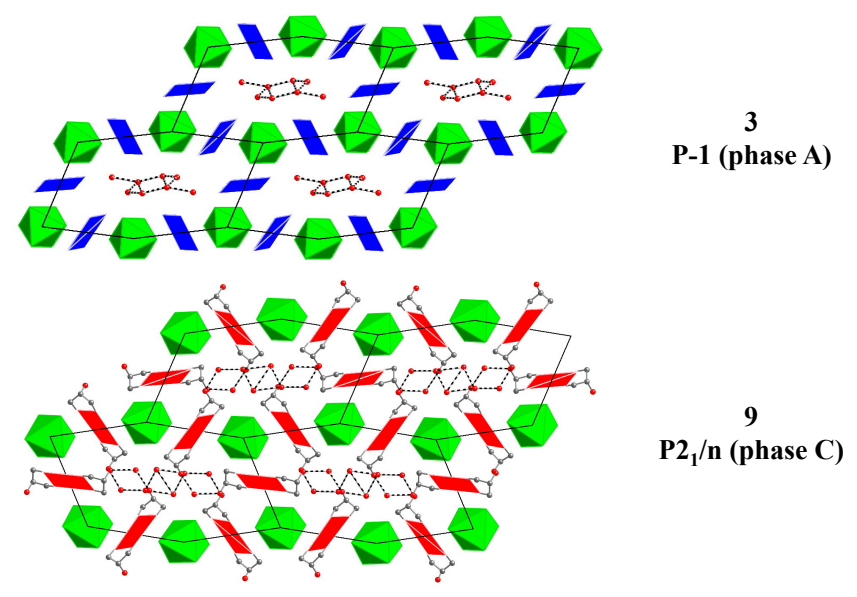

Figure 1: Schematic recognition pattern of $2 \mathrm{D}(6,3) \mathrm{H}$ bonded networks formed by combination of dications $\left(\mathbf{1} \cdot 2 \mathrm{H}^{+}\right)$(compound $\mathbf{3}$ ) and $(\mathbf{2} \cdot 2 \mathrm{H})^{+}$(compound $\mathbf{9}$ ) with $\left[\mathrm{Fe}(\mathrm{CN})_{6}\right]^{3-21}$

Through this study we intend to explore the potential recognition pattern in these two components systems $\left(\left[\mathrm{Fe}(\mathrm{CN})_{6}\right]^{3-}\right.$ and $\mathbf{Y}-2 \mathrm{H}^{+}(\mathbf{Y}=1$ or 2$)$ by investigating the solid state solutions formed by mixing the organic ligand leading to $2 \mathrm{D} \mathrm{H}$ bonded solid solutions of formula $\left(1-2 \mathrm{H}^{+}\right)_{3 x}\left(2-2 \mathrm{H}^{+}\right)_{3(1-}$ x) $\left(\left[\mathrm{Fe}(\mathrm{CN})_{6}\right]^{3-}{ }_{2}\right) \cdot \mathrm{n} \mathrm{H}_{2} \mathrm{O}$, compounds 3-9, $(0<\mathrm{x}<1)$. Their related thermal properties will also be discussed.

\section{Results and discussion}

\section{Preliminary study}

There are two main issues when analysing the structures of the resulting solid solutions of formula $\left(1-2 \mathrm{H}^{+}\right)_{3 x}\left(2-2 \mathrm{H}^{+}\right)_{3(1-}$ x) $\left(\left[\mathrm{Fe}(\mathrm{CN})_{6}\right]^{3-}{ }_{2}\right) \cdot \mathrm{n} \mathrm{H}_{2} \mathrm{O}$. The recognition pattern between anions and cations is based on the principle of a deformed and flexible honeycomb-like structure, held by hydrogen bonds.

1) The first issue is linked with the deformation of the hexagons in the honeycomb-like structure, induced by a shift of the $\left(2-2 \mathrm{H}^{+}\right)$cations, due to short $\mathrm{O}-\mathrm{H} \cdots \mathrm{OH}$ interactions, as shown in figure 1 . It is thus related to the pavage adopted by the resulting $(6,3)$ network.

2) The second issue is the precise location of both organic cations $\left(1-2 \mathrm{H}^{+}\right)$and $\left(2-2 \mathrm{H}^{+}\right)$in the network formed by the solid solutions, since they may be crystallographically distinguished.

We performed a preliminarily model analysis to explore the potential localisation of the cations $\left(1-2 \mathrm{H}^{+}\right)$and $\left(2-2 \mathrm{H}^{+}\right)$in the 
solid solutions of formula $\left(1-2 \mathrm{H}^{+}\right)_{3 x}\left(2-2 \mathrm{H}^{+}\right)_{3(1-x)}\left(\left[\mathrm{Fe}(\mathrm{CN})_{6}\right]^{3-} 2\right)$.n $\mathrm{H}_{2} \mathrm{O}$. There are four (five) peculiar $x$ values to be analysed: $\mathrm{x}=1 / 6$ (or $\mathrm{x}=5 / 6)\left(1\left(1-2 \mathrm{H}^{+}\right)\right.$and $5\left(2-2 \mathrm{H}^{+}\right)$in a 6 -membered rings), $x=1 / 3, x=1 / 2, x=2 / 3$.

The representation of the different isomeric patterns with higher symmetry (other lower symmetries are not depicted here) is displayed in figure 2 , together with the corresponding unit cell. One can note that for the $x$ value $=1 / 2$, two different isomeric 2D H bonded networks, with different unit cells, are determined (figure $2 \mathrm{c}$ and $2 \mathrm{~d}$ ).

In this context, we can see that the precise location of the organic cations $\left(1-2 \mathrm{H}^{+}\right)$and $\left(2-2 \mathrm{H}^{+}\right)$can highly influence the unit cell, and the space group in which the $\mathrm{H}$-bonded system may crystallise.

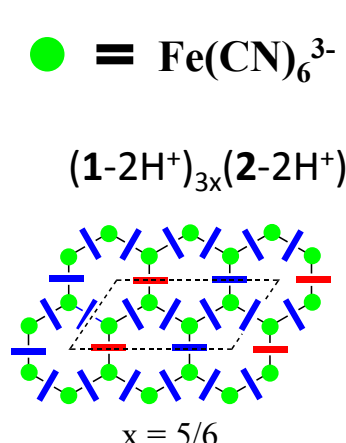

(a)

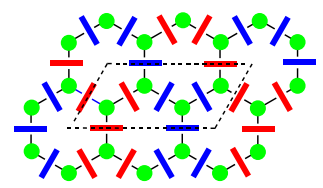

$\mathrm{x}=3 / 6$

(c)

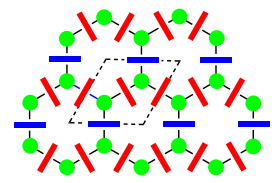

$\mathrm{x}=2 / 6$

(e)

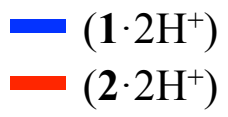

$\left(\left[\mathrm{Fe}(\mathrm{CN})_{6}\right]^{3-}{ }_{2}\right)$

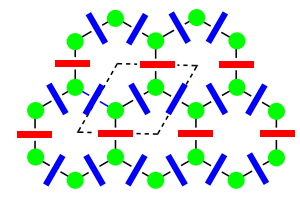

$\mathrm{x}=4 / 6$

(b)

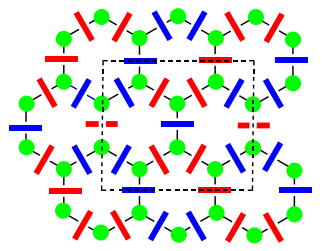

$\mathrm{x}=3 / 6$

(d)

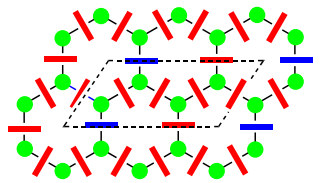

$\mathrm{x}=1 / 6$

(f)
Figure 2: Six possible high symmetry arrangements in the $\left(\mathbf{1}-2 \mathrm{H}^{+}\right)_{3 \times}\left(\mathbf{2}-2 \mathrm{H}^{+}\right)_{3(1-}$ ${ }_{x)}\left(\left[\mathrm{Fe}(\mathrm{CN})_{6}\right]^{3-}{ }_{2}\right)$ solid solutions with the following composition for $x: x=5 / 6$ (a), $x=4 / 6(b), x=3 / 6$ (c), $x=3 / 6$ (d), $x=2 / 6$ (e) or $x=1 / 6(f)$.

\section{Description and discussion of the obtained solid- state solutions}

Single crystals of mixtures of bisamidinium dications (1$2 \mathrm{H}^{+}$) and $\left(2-2 \mathrm{H}^{+}\right)$combined with hexacyanoferrate(III), have been synthesized by solvent diffusion method in water solutions (see experimental part and also ref. 21). For the synthesis of solid solution with formula $\left(1-2 \mathrm{H}^{+}\right)_{3 x}\left(2-2 \mathrm{H}^{+}\right)_{3(1-}$ x) $\left(\left[\mathrm{Fe}(\mathrm{CN})_{6}\right]^{3-}{ }_{2}\right)$.n $\mathrm{H}_{2} \mathrm{O}$, we used the $\left(1-2 \mathrm{H}^{+}\right) /\left(2-2 \mathrm{H}^{+}\right)$ratios for the modelling study of isomeric solid solutions: $x=5 / 6, x=2 / 3$, $x=1 / 2, \quad x=1 / 3$ or $x=1 / 6$ (figure 2 ), leading to crystalline compounds 4-8 respectively. All the obtained crystals have been analysed by $X$ ray diffraction on single crystals and the observed ratios were refined and slightly different from the starting ratios, as seen in table 2: this behaviour was already documented for other molecular self-assembled systems. ${ }^{22}$

It is also important to note that for compounds 4-8 (solid solutions), relative oxygen occupancies of the hydroxyl group in $\left(2-2 \mathrm{H}^{+}\right)$, were refined around each $\left(2-2 \mathrm{H}^{+}\right)$cationic units and the refined occupation rate values are reported in table 2 .

Table 2: Data for the $\left(1-2 \mathrm{H}^{+}\right)_{3 x}\left(2-2 \mathrm{H}^{+}\right)_{3(1-x)}\left(\left[\mathrm{Fe}(\mathrm{CN})_{6}\right]^{3-}{ }_{2}\right) \cdot \mathrm{nH}_{2} \mathrm{O}$ solid solutions (compounds 3-9): observed phases, isomeric patterns and refined occupation rates for $\mathrm{O}$ in cation $\left(2-2 \mathrm{H}^{+}\right)$

\begin{tabular}{|c|c|c|c|c|}
\hline & $x$ & Phase & $\begin{array}{l}\text { Isomeric } \\
\text { pattern }\end{array}$ & $\begin{array}{c}\text { Refined } \\
\text { occupation } \\
\text { rate of } \mathrm{O} \text { in } \\
\text { cation }(2-2 \mathrm{H})^{+}\end{array}$ \\
\hline$\left[1-2 \mathrm{H}^{+}\right]_{3}\left[\mathrm{Fe}(\mathrm{CN})_{6}\right]^{3-}{ }_{2} \cdot 7 \mathrm{H}_{2} \mathrm{O}$ & 1 & A P $\overline{1}$ & - & - \\
\hline$\left(\left[1-2 \mathrm{H}^{+}\right]_{0.80}\left[\left(2-2 \mathrm{H}^{+}\right]_{0.20}\right)_{3}\left[\mathrm{Fe}(\mathrm{CN})_{6}\right]^{3-}{ }_{2} .7 \mathrm{H}_{2} \mathrm{O} 4\right.$ & 0.80 & A $P \overline{1}$ & $\begin{array}{c}1 / 3 \\
\text { fig. } 2 e \\
\end{array}$ & 0.3 and 0.3 \\
\hline$\left(\left[1-2 \mathrm{H}^{+}\right]_{0.67}\left[\left(2-2 \mathrm{H}^{+}\right]_{0.33}\right)_{3}\left[\mathrm{Fe}(\mathrm{CN})_{6}\right]^{3-}{ }_{2} .8 \mathrm{H}_{2} \mathrm{O} 5\right.$ & 0.67 & B P $21 / \mathrm{n}$ & $\begin{array}{c}1 / 3 \\
\text { fig. } 2 e\end{array}$ & 0.5 and 0.5 \\
\hline$\left(\left[1-2 \mathrm{H}^{+}\right]_{0.53}\left[\left(2-2 \mathrm{H}^{+}\right]_{0.47}\right)_{3}\left[\mathrm{Fe}(\mathrm{CN})_{6}\right]^{3-}{ }_{2} \cdot 8 \mathrm{H}_{2} \mathrm{O} 6\right.$ & 0.53 & B $\mathrm{P} 2{ }_{1} / \mathrm{n}$ & $\begin{array}{c}1 / 3 \\
\text { fig. } 2 e\end{array}$ & 0.7 and 0.7 \\
\hline$\left(\left[1-2 \mathrm{H}^{+}\right]_{0.37}\left[\left(2-2 \mathrm{H}^{+}\right]_{0.63}\right)_{3}\left[\mathrm{Fe}(\mathrm{CN})_{6}\right]^{3-}{ }_{2} .8 \mathrm{H}_{2} \mathrm{O} 7\right.$ & 0.37 & B $\mathrm{P} 2{ }_{1} / \mathrm{n}$ & - & $0.8,0.8$ and 0.3 \\
\hline$\left(\left[1-2 \mathrm{H}^{+}\right]_{0.17}\left[\left(2-2 \mathrm{H}^{+}\right]_{0.83}\right)_{3}\left[\mathrm{Fe}(\mathrm{CN})_{6}\right]^{3-}{ }_{2} .8 \mathrm{H}_{2} \mathrm{O} 8\right.$ & 0.17 & $\mathrm{CP} 2{ }_{1} / \mathrm{n}$ & - & $0.8,0.8$ and 0.9 \\
\hline$\left[2-2 \mathrm{H}^{+}\right]_{3}\left[\mathrm{Fe}(\mathrm{CN})_{6}\right]^{3-}{ }_{2} .8 \mathrm{H}_{2} \mathrm{O}$ & 0 & $\mathrm{CP} 2{ }_{1} / \mathrm{n}$ & - & 1 \\
\hline
\end{tabular}

Crystallographic data for 4-8 are summarized in the crystallographic Table 3 . For $\mathbf{4 - 8}$, the bond and angles in the solid solutions are not discussed here since these values are close to the reported values for $\mathbf{3}$ and $\mathbf{9 . 2 1}$ The location of the water molecules present in the lattice will also not be discussed. Compounds 5-8 present 8 water molecules in the unit cell, whereas compound 4 presents only 7 water molecules in the unit cell (see table 2 ).

Observed pavages of the $(6,3)$ network

Compound 4-8 present all the same recognition pattern between anions and cations, but differ by the pavage adopted by the $(6,3)$ network.

Compound 4 , presenting a $x$ value $x=0.80$, crystallizes in the triclinic $\mathrm{P} \overline{1}$ space group and is isostructral (isomorphous and isometric) with $\mathbf{3}$ (Phase A). ${ }^{12,13 a, b, 21}$ It is important to note that in both compounds $\mathbf{3}$ and $\mathbf{4}$, the same number of water molecules was found: 7 .

Compound 8 , presenting a $x$ value $x=0.17$, crystallizes in the monoclinic $\mathrm{P} 2_{1} / \mathrm{n}$ space group and is isostructral (isomorphous and isometric) with 9 (Phase C), and 8 and 9 present the same number of water molecules in the lattice: 8 ;

For compounds 5-7, presenting a $\mathrm{x}$ value $0.80>\mathrm{x}>0.17$, a new crystallographic phase has been evidenced, with monoclinic $\mathrm{P} 2_{1} / \mathrm{n}$ space group (Phase $\mathrm{B}$ ), but with different cell parameters (metrics) compared to the one of phase $\mathbf{C}$ (see tables 2 and 3 ). 
The obtained solid solutions (compounds 4-8) crystallizes reproducibly in three different phases: $\mathbf{A}, \mathbf{B}$ and $\mathbf{C}$.

These crystallographic phases A, B and C display here different pavages of the deformed honeycomb-like structure, as schematically presented in figure 3 . They result from the metric constraints imposed by the use of $\left[\mathrm{Fe}(\mathrm{CN})_{6}\right]^{3-}$ and also from the recognition between $\left(2-2 \mathrm{H}^{+}\right)$cations, through specific $\mathrm{H}$ bonds. The obtained 2D patterns (pavage) are topologically equivalent, but different from a metric point of view. They correspond to the pmg2, pgg2 and $p g$ Wallpaper groups for phases $\mathbf{A}, \mathbf{B}$ and $\mathbf{C}$ respectively. ${ }^{23}$

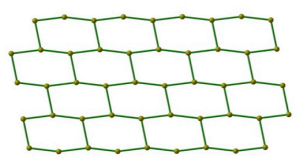

Phase A

(a)

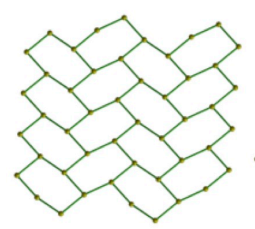

Phase B

(b)

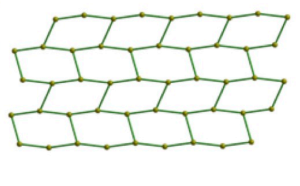

Phase C

(c)
Figure 3: Schematic representations of the recognition patterns for the three types of deformed honeycomb-like 2D networks obtained for Phase A (a), Phase B (b) and Phase C (c). Yellow circles represent the metal centres.

Localization of the $\left(\mathrm{X}-2 \mathrm{H}^{+}\right)$cations in the unit cell

For 4-8, concerning the location of the cations $\left(1-2 \mathrm{H}^{+}\right)$and $\left(2-2 \mathrm{H}^{+}\right)$in the networks, only one isomer (figure $2 \mathrm{e}$, modelling, $x=1 / 3$ ) is observed, among the 6 that were displayed in modelling. For $4-8$, the precise $x$ value is then reached by a different occupancy rate for the oxygen atom in $\left(2-2 \mathrm{H}^{+}\right)$, as shown in table 2.

Surprisingly, we found that for compounds 4-6 (x varying between 0.80 and 0.53 , figure $4 a$ or $b$ ), the location of the observed $\left(1-2 \mathrm{H}^{+}\right)$and $\left(2-2 \mathrm{H}^{+}\right)$cations within the network corresponds to the pattern described for the value $x=1 / 3$ (figure 2e), independently on the observed pavage (phase $\mathbf{A}$ or phase B).

For 7 and 8 ( $x$ values below 0.53, phase B or phase C, figures $4 \mathrm{c}$ and $\mathrm{d}),\left(2-2 \mathrm{H}^{+}\right)$cations are occupying all the possible locations with increasing occupancies rates, and no positional isomer is observed.

This isomer ( $x=1 / 3$, figure $2 e$ ), is mainly favoured by the interactions, through $\mathrm{H}$ bonds, of two hydroxyl groups belonging to adjacent $\left(2-2 \mathrm{H}^{+}\right)$cations located on each side of the $\left[\mathrm{Fe}(\mathrm{CN})_{6}\right]^{3-}$ anions, with O-O distances presented in table 4. This precise location of the $\left(2-2 \mathrm{H}^{+}\right)$cations enables the formation of $\mathrm{O}-\mathrm{H} \cdots \mathrm{OH}$ interactions, as shown by the decrease of the O-O distance when $x$ is decreasing (see table 4). As already mentioned, the hydroxyl groups also interact with the water molecules located inside the cavities of the honeycomblike structure.

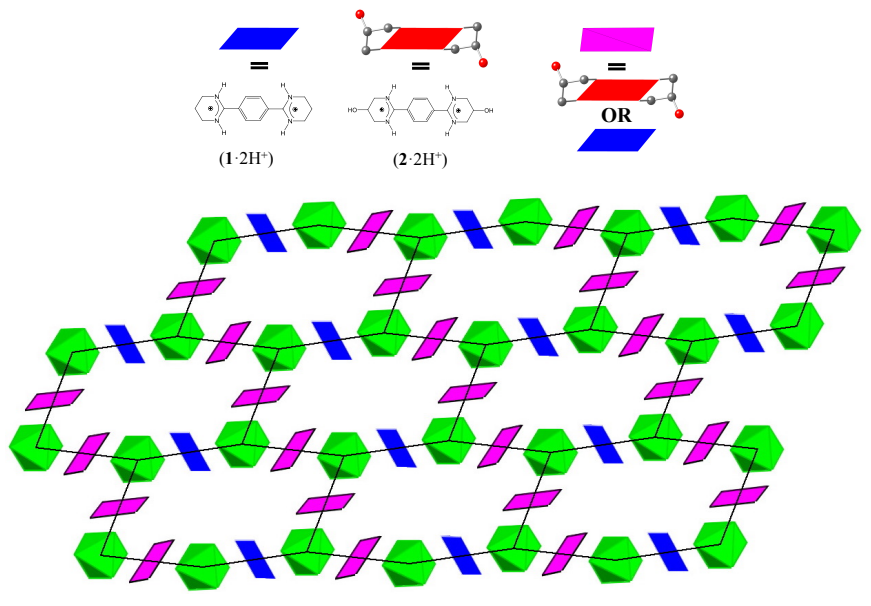

a

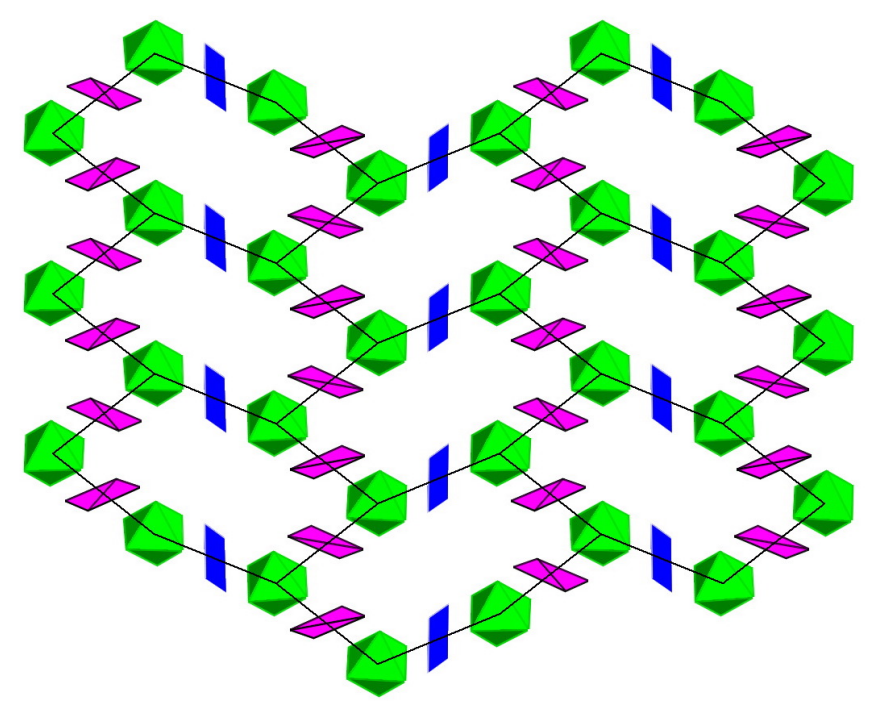

b

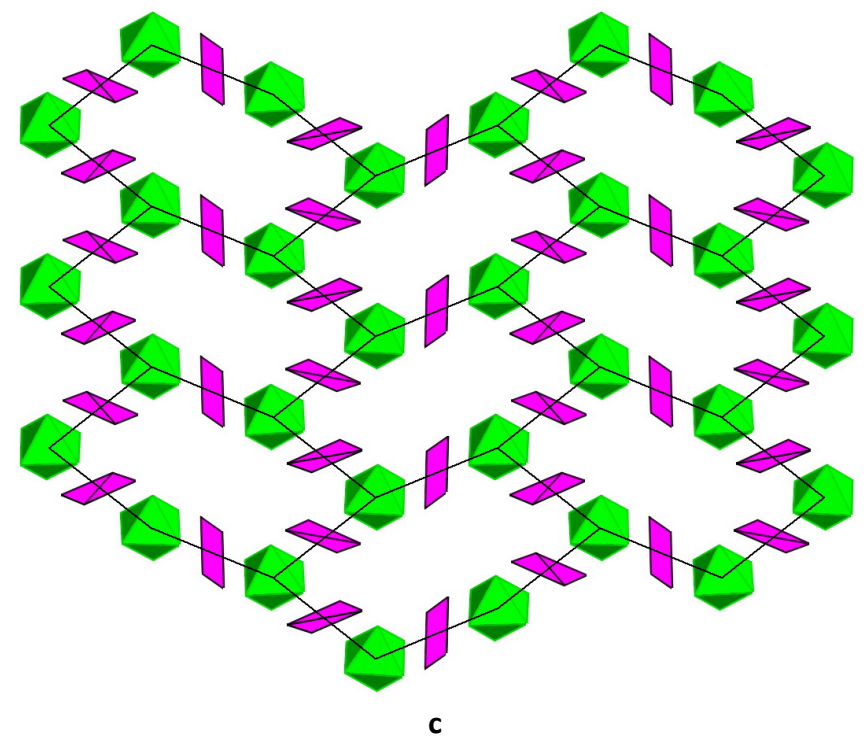




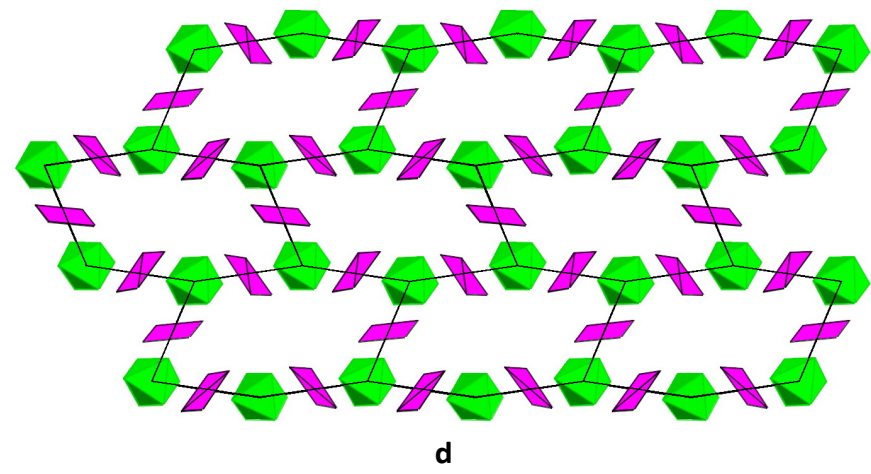

Figure 4: Polyhedral representations of the isomeric pattern for localisation of $\left(\mathbf{1}-2 \mathrm{H}^{+}\right)$(as blue losange) and $\left(2-2 \mathrm{H}^{+}\right)$(as violet losange with a partial occupation rate of $\left.\left(2-2 \mathrm{H}^{+}\right)\right)$in the solid solutions $\left(1-2 \mathrm{H}^{+}\right)_{3 \times}\left(2-2 \mathrm{H}^{+}\right)_{3(1-x)}\left(\left[\mathrm{Fe}(\mathrm{CN})_{6}\right]^{3-}{ }_{2}\right)$ for a) $\mathbf{4}(\mathrm{x}=$ 0.80 and phase A) b) 5 and 6 ( $x=0.67$ and 0.53 phase B) c) 7 ( $x=0.37$ and phase B) and d) $8(x=0.17$ and phase $C)$. The green octahedron represents the $\left[\mathrm{Fe}(\mathrm{CN})_{6}\right]^{3}$ anions.

Table 4: Data for the $\left(1-2 \mathrm{H}^{+}\right)_{3 \times}\left(2-2 \mathrm{H}^{+}\right)_{3(1-x)}\left(\left[\mathrm{Fe}(\mathrm{CN})_{6}\right]^{3-}{ }_{2}\right)$ solid solutions (compounds 3-9): observed phases, isomeric patterns and occupation rates for $\mathrm{O}$ in cation $\left(\mathbf{2}-2 \mathrm{H}^{+}\right)$

\begin{tabular}{|c|c|c|}
\hline & $x$ & $\mathrm{~d}_{\mathrm{O}-\mathrm{O}}$ in $\left(2-2 \mathrm{H}^{+}\right](\AA)$ \\
\hline$\left[1-2 \mathrm{H}^{+}\right]_{3}\left[\mathrm{Fe}(\mathrm{CN})_{6}\right]^{-3}{ }_{2}$ & 1 & - \\
\hline$\left(\left[1-2 \mathrm{H}^{+}\right]_{0.80}\left[2-2 \mathrm{H}^{+}\right]_{0.20}\right)_{3}\left[\mathrm{Fe}(\mathrm{CN})_{6}\right]^{3-}{ }_{2} 4$ & 0.80 & $3.010(5)$ \\
\hline$\left(\left[1-2 \mathrm{H}^{+}\right]_{0.67}\left[\left(2-2 \mathrm{H}^{+}\right]_{0.33}\right)_{3}\left[\mathrm{Fe}(\mathrm{CN})_{6}\right]^{3-}{ }_{2} \mathbf{5}\right.$ & 0.67 & $2.933(6)$ \\
\hline$\left(\left[1-2 \mathrm{H}^{+}\right]_{0.53}\left[\left(2-2 \mathrm{H}^{+}\right]_{0.47}\right)_{3}\left[\mathrm{Fe}(\mathrm{CN})_{6}\right]^{3-}{ }_{2} \mathbf{6}\right.$ & 0.53 & $2.861(4)$ \\
\hline$\left(\left[1-2 \mathrm{H}^{+}\right]_{0.37}\left[\left(2-2 \mathrm{H}^{+}\right]_{0.63}\right)_{3}\left[\mathrm{Fe}(\mathrm{CN})_{6}\right]^{3-}{ }_{2} 7\right.$ & 0.37 & $2.842(5)$ \\
\hline$\left(\left[1-2 \mathrm{H}^{+}\right]_{0.17}\left[\left(2-2 \mathrm{H}^{+}\right]_{0.83}\right)_{3}\left[\mathrm{Fe}(\mathrm{CN})_{6}\right]^{3-}{ }_{2} 8\right.$ & 0.17 & $2.834(6)$ \\
\hline$\left[2-2 \mathrm{H}^{+}\right]_{3}\left[\mathrm{Fe}(\mathrm{CN})_{6}\right]^{3-2}$ & 0 & $2.828(5)$ \\
\hline
\end{tabular}

\section{XRPD diagrams}

For compounds $4-\mathbf{8}$, the phase purity was confirmed by Xray powder diffraction. XRPD diagrams of compounds crystallising in phase $\mathbf{A}$ ( 3 and 4 ) are displayed in figure 5, the diagrams for compounds crystallising in phase B (5-7) are displayed in figure 6 and the ones crystallising in phase $\mathbf{C}$ (8 and 9) are presented in figure 7. This is another proof for the obtention of one pure polycrystalline phase for each defined $x$ value in the solid solutions of formula $\left(1-2 \mathrm{H}^{+}\right)_{3 x}\left(2-2 \mathrm{H}^{+}\right)_{3(1-}$ $\left.{ }_{x}\right)\left(\left[\mathrm{Fe}(\mathrm{CN})_{6}\right]^{3-}{ }_{2}\right) \cdot \mathrm{n} \mathrm{H}_{2} \mathrm{O}$.
Phase A

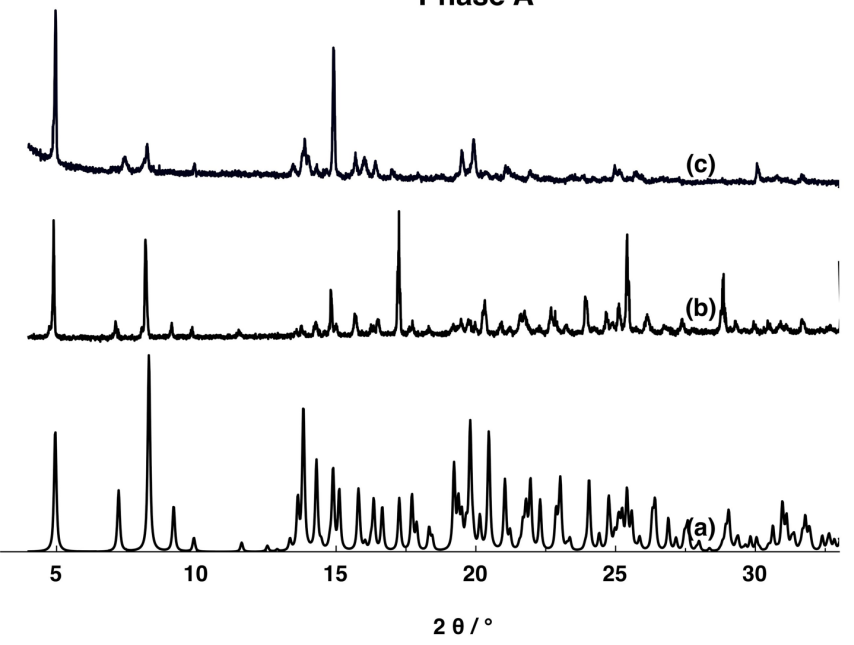

Figure 5: Experimental XRPD patterns for $\left(1-2 \mathrm{H}^{+}\right)_{3 \times}\left(2-2 \mathrm{H}^{+}\right)_{3(1-x)}\left(\left[\mathrm{Fe}(\mathrm{CN})_{6}\right]^{3-}{ }_{2}\right) \cdot \mathrm{nH}_{2} \mathrm{O}$ solid solutions crystallising in phase $\mathbf{A}, \mathbf{3}(\mathrm{b})$ and $\mathbf{4}(\mathrm{x}=0.80)(\mathrm{c})$, compared to the diagram simulated for $\mathbf{3}$ (a).

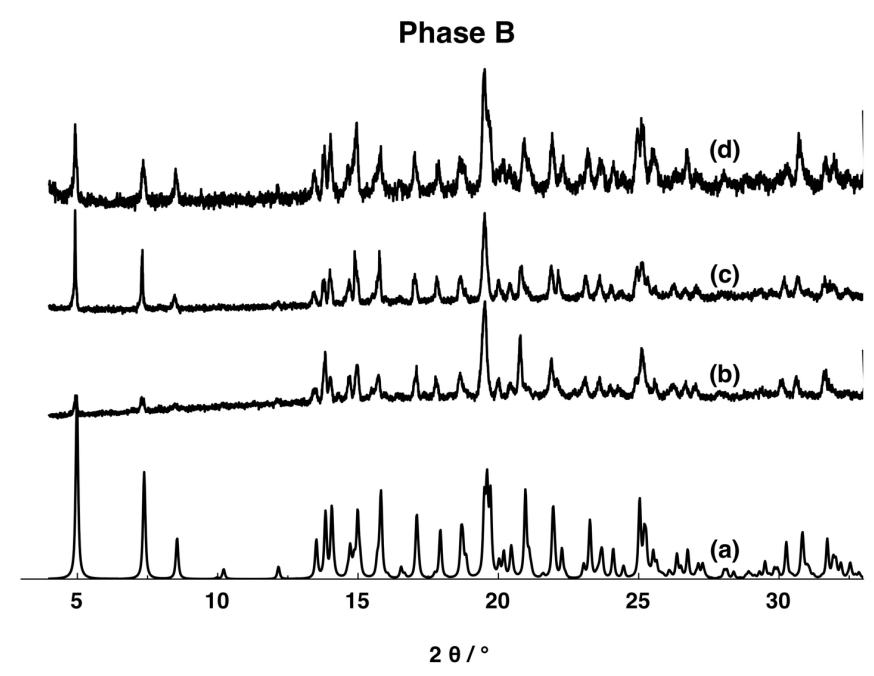

Figure 6: Experimental XRPD patterns for $\left(1-2 \mathrm{H}^{+}\right)_{3 x}\left(2-2 \mathrm{H}^{+}\right)_{3(1-x)}\left(\left[\mathrm{Fe}(\mathrm{CN})_{6}\right]^{3-}{ }_{2}\right) \cdot \mathrm{nH}_{2} \mathrm{O}$ solid solutions crystallising in phase $\mathbf{B}, \mathbf{5}(\mathrm{x}=0.67)(\mathrm{b}), \mathbf{6}(\mathrm{x}=0.53)(\mathrm{c})$ and $\mathbf{7}(\mathrm{x}=0.37)$ d) compared to the diagram simulated for $\mathbf{6}(\mathrm{a})$.

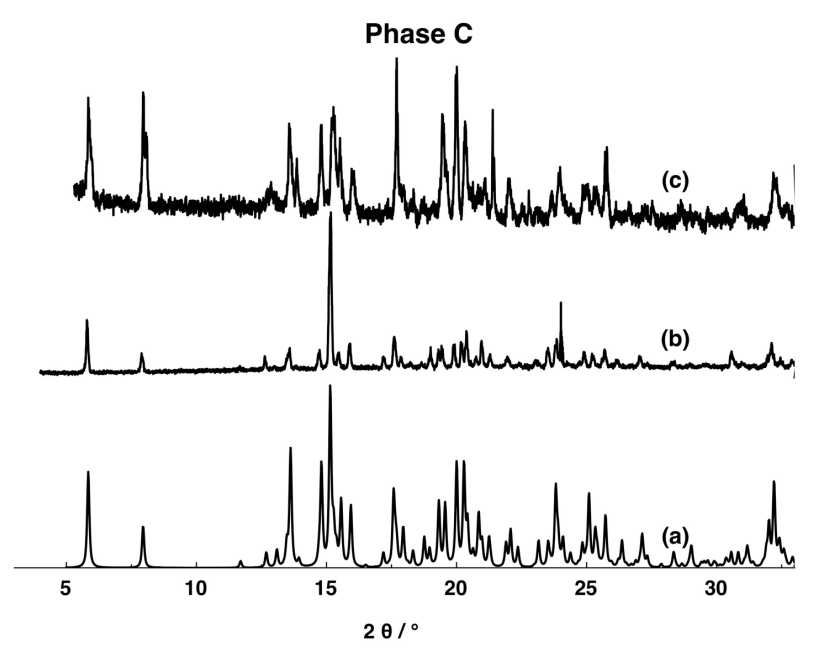


Figure 7: Experimental XRPD patterns for $\left(1-2 \mathrm{H}^{+}\right)_{3 x}\left(2-2 \mathrm{H}^{+}\right)_{3(1-x)}\left(\left[\mathrm{Fe}(\mathrm{CN})_{6}\right]^{3-}{ }_{2}\right) \cdot \mathrm{nH}_{2} \mathrm{O}$ solid solutions crystallising in phase $\mathbf{C}, \mathbf{8}(\mathrm{x}=0.17)$ (b) and $\mathbf{9}(\mathrm{c})$, compared to the diagram simulated for $\mathbf{9}$ (a).

\section{Thermal properties}

The thermal properties of the formed solid-solutions were investigated using TGA measurements, as already shown in the pure $\left(1-2 \mathrm{H}^{+}\right)_{3}\left(\left[\mathrm{Fe}(\mathrm{CN})_{6}\right]_{2} .7 \mathrm{H}_{2} \mathrm{O}\right)$ and $\left(2-2 \mathrm{H}^{+}\right)_{3}\left(\left[\mathrm{Fe}(\mathrm{CN})_{6}\right]_{2} .8 \mathrm{H}_{2} \mathrm{O}\right)$ phases that exhibit respectively water release temperatures of 100 and $150^{\circ} \mathrm{C} .{ }^{21}$

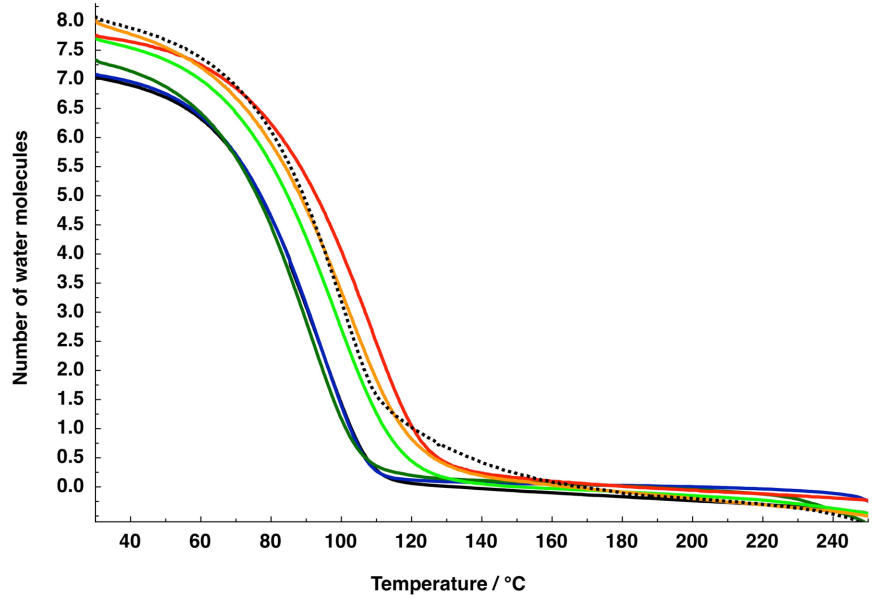

Figure 8: TGA curves (heat of rate $10^{\circ} \mathrm{C} / \mathrm{mn}$ ) obtained for compounds of general formula $\left(1-2 \mathrm{H}^{+}\right)_{3 \times}\left(2-2 \mathrm{H}^{+}\right)_{3(1-x)}\left(\left[\mathrm{Fe}(\mathrm{CN})_{6}\right]^{3-}{ }_{2}\right) \cdot \mathrm{nH}_{2} \mathrm{O} 3(\mathrm{x}=1)$ (black), $4(\mathrm{x}=0.80)$ (blue), $5(x=0.67)$ (dark green), $6(x=0.53)$ (light green), $7(x=0.37)$ (red), $8(x=0.17)$ (orange) and $9(x=0)$ (dashed black).

The TGA traces (figure 8) confirm the water molecule contents of the polycrystalline samples for 4-8, varying from 7 to 8 , also confirmed by $X$ ray diffraction on single crystals and by EA.

As already shown, ${ }^{21}$ compared to compound $\mathbf{3}$, the water molecules in the channels of compound 9 are stabilized by the $\mathrm{H}$-bonding interactions with the $\mathrm{OH}$ groups in $2-2 \mathrm{H}^{+}$, resulting in the higher dehydration temperature for $\mathrm{ca} .50^{\circ} \mathrm{C}$.

Thus, for the $\left(1-2 \mathrm{H}^{+}\right)_{3 x}\left(2-2 \mathrm{H}^{+}\right)_{3(1-x)}\left(\left[\mathrm{Fe}(\mathrm{CN})_{6}\right]^{3-} 2\right) \cdot \mathrm{n} \mathrm{H}_{2} \mathrm{O}$ solid solutions, the water release temperature increases when $\mathrm{x}$ decreases because of the increasing hydrophilic nature of the channels generated with $2-2 \mathrm{H}^{+}$: at $10^{\circ} \mathrm{C} / \mathrm{mn}$ heating rate, it varies between $100^{\circ} \mathrm{C}\left(\left(1-2 \mathrm{H}^{+}\right)_{3}\left(\left[\mathrm{Fe}(\mathrm{CN})_{6}\right]^{3-}{ }_{2}\right)\right)$ and $150^{\circ} \mathrm{C}((2-$ $\left.\left.2 \mathrm{H}^{+}\right)_{3}\left(\left[\mathrm{Fe}(\mathrm{CN})_{6}\right]^{3-} 2\right)\right)$.

However, the temperature of water release is not linear with the $x$ value.

The temperature of water release is low (around $100^{\circ} \mathrm{C}$ ) for compounds with high $x$ values (3, 4 and 5). With lower $x$ values, the release temperature increases rapidly to $130^{\circ} \mathrm{C}(6)$ and $140^{\circ} \mathrm{C}(\mathbf{7}$ and 8$)$ : this is in accordance with the fact that there is no preferential localization of the cations at the periphery of the channels, and that there is a statistic distribution of the $\left(2-2 \mathrm{H}^{+}\right)$cations in the formed structure in 7 and $\mathbf{8}$, as shown in figure $4 \mathrm{~d}$.

\section{Conclusions}

A new family of inorganic-organic hybrid non-isostructural solid solution has been synthesised and crystallized: (1$\left.2 \mathrm{H}^{+}\right)_{3 \times}\left(2-2 \mathrm{H}^{+}\right)_{3(1-x)}\left(\left[\mathrm{Fe}(\mathrm{CN})_{6}\right]^{3-}{ }_{2}\right) \cdot \mathrm{n} \mathrm{H}_{2} \mathrm{O}$, by changing the ratio of $\mathrm{H}$-bond donors $\mathrm{Y}-2 \mathrm{H}^{+}(\mathrm{Y}=1$ or $2,0<\mathrm{x}<1$ and $\mathrm{n}=7$ or 8$)$.

Their structure has been carefully analysed and refined. The predictable compositions are confirmed by the single crystal XRD and TGA analysis. We were able to show that finely tuning of the $x$ value allowed us to evidences three different crystallographic phases, which corresponds to three different pavages of the $(6,3)$ network for solid state solutions, and only one preferential localization of the organic cations within the structure. The simplified structural phase diagram can be derived from these data, as shown in figure 9.
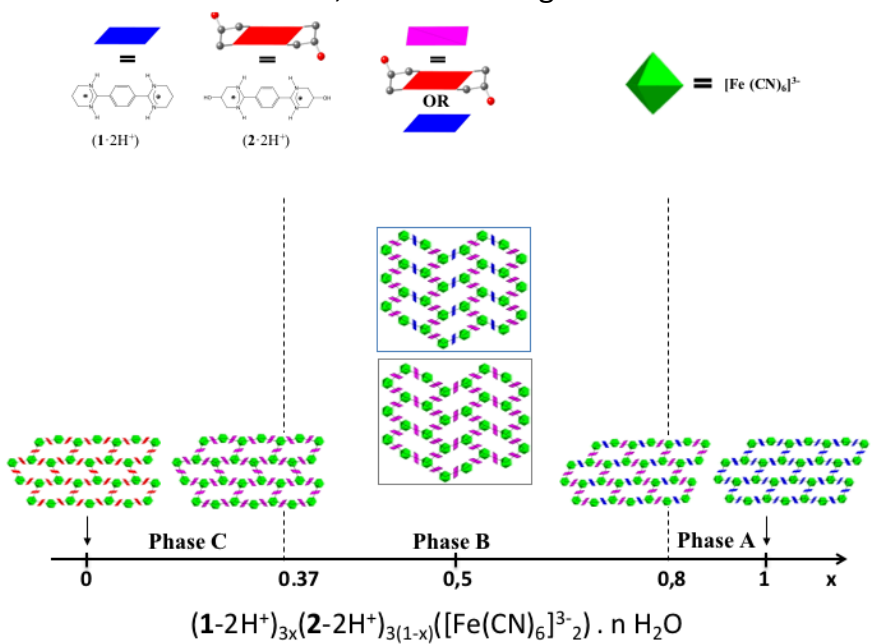

Figure 9: Simplified structural phase diagram for solid solutions of general formula $\left(1-2 \mathrm{H}^{+}\right)_{3 \times}\left(2-2 \mathrm{H}^{+}\right)_{3(1-x)}\left(\left[\mathrm{Fe}(\mathrm{CN})_{6}\right]^{3-}{ }_{2}\right) \cdot \mathrm{nH}_{2} \mathrm{O}$, depending on the $\mathrm{x}$ values.

The driving force for this observation is the formation of hydrogen bonds between adjacent $\left(2-2 \mathrm{H}^{+}\right)$cations within the network. The control of porous properties in solid solution is also explained to the light of the localization of the cations in the network.

\section{Experimental section}

FT-IR spectra were recorded on a Perkin Elmer ATR spectrometer.

Microanalyses were performed by the Service de Microanalyses de la Fédération de Recherche Chimie, Université de Strasbourg, Strasbourg, France.

Bisamidinium dications $\left(1-2 \mathrm{H}^{+}\right)^{13 a, b}$ and $\left(2-2 \mathrm{H}^{+}\right)^{21}$ have been prepared as described in the corresponding literature. Compounds $\mathbf{3}$ and $\mathbf{9}$ have been prepared as reported in the literature. ${ }^{21}$ 


\section{General method of synthesis for 4-8}

The solution of bisamidinium dications $\left(1-2 \mathrm{H}^{+}\right) /\left(2-2 \mathrm{H}^{+}\right)$in $\mathrm{EtOH} / \mathrm{H}_{2} \mathrm{O}(1 \mathrm{~mL} / 1 \mathrm{~mL})$ was carefully layered on top of a $\mathrm{H}_{2} \mathrm{O}$ $(2 \mathrm{~mL})$ solution of $\mathrm{K}_{3}\left[\mathrm{Fe}(\mathrm{CN})_{6}\right]\left(1.7 \mathrm{mg}, 5^{*} 10^{-3} \mathrm{mmol}\right)$ in a test tube. After $c a$. three week at room temperature, light green single crystals appeared in the tube.

\section{Synthesis of compound 4}

The following $\left(1-2 \mathrm{H}^{+}\right) /\left(2-2 \mathrm{H}^{+}\right)$ratio was used: $2.5 \mathrm{mg} / 0.5 \mathrm{mg}$, (6.5*10-3 $\mathrm{mmol} / 1.3^{*} 10^{-3} \mathrm{mmol}$ ). Yield: $69 \%$.

Elemental analysis: calc. (\%) for $\left(\left[\mathrm{C}_{14} \mathrm{H}_{20} \mathrm{~N}_{4}\right]_{0.80}\left[\mathrm{C}_{14} \mathrm{H}_{20} \mathrm{~N}_{4}\right.\right.$ $\left.\left.\mathrm{O}_{2}\right]_{0.20}\right)_{3}\left[\mathrm{Fe}^{\prime \prime \prime}(\mathrm{CN})_{6}\right]^{3-}{ }_{2}$. $6.8 \quad \mathrm{H}_{2} \mathrm{O}: \mathrm{C}=49.94 ; \mathrm{H}=5.71 ; \mathrm{N}=25.89$.

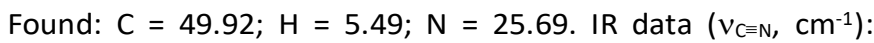
2114.6.

\section{Synthesis of compound 5}

The following $\left(1-2 \mathrm{H}^{+}\right) /\left(2-2 \mathrm{H}^{+}\right)$ratio was used: $2.0 \mathrm{mg} / 1.0 \mathrm{mg}$, (5.2*10-3 $\left.\mathrm{mmol} / 2.6^{*} 10^{-3} \mathrm{mmol}\right)$. Yield: $65 \%$.

Elemental analysis: calc. (\%) for $\left(\left[\mathrm{C}_{14} \mathrm{H}_{20} \mathrm{~N}_{4}\right]_{0.53}\left[\mathrm{C}_{14} \mathrm{H}_{20} \mathrm{~N}_{4}\right.\right.$ $\left.\left.\mathrm{O}_{2}\right]_{0.47}\right)_{3}\left[\mathrm{Fe}(\mathrm{CN})_{6}\right]^{3-}{ }_{2}$. $7.4 \quad \mathrm{H}_{2} \mathrm{O}: \mathrm{C}=48.57 ; \mathrm{H}=5.65 ; \mathrm{N}=25.17$. Found: $C=48.56 ; H=5.47 ; N=25.10$. IR data $\left(v_{C \equiv N}, \mathrm{~cm}^{-1}\right)$ : 2114.5.

\section{Synthesis of compound 6}

The following $\left(1-2 \mathrm{H}^{+}\right) /\left(2-2 \mathrm{H}^{+}\right)$ratio was used: $1.5 \mathrm{mg} / 1.5 \mathrm{mg}$, (3.9*10-3 $\mathrm{mmol} / 3.9 * 10^{-3} \mathrm{mmol}$ ). Yield: $72 \%$.

Elemental analysis: calc. (\%) for $\left(\left[\mathrm{C}_{14} \mathrm{H}_{20} \mathrm{~N}_{4}\right]_{0.67}\left[\mathrm{C}_{14} \mathrm{H}_{20} \mathrm{~N}_{4}\right.\right.$ $\left.\left.\mathrm{O}_{2}\right]_{0.33}\right)_{3}\left[\mathrm{Fe}(\mathrm{CN})_{6}\right]^{3-}{ }_{2}$. $7.2 \quad \mathrm{H}_{2} \mathrm{O}: \mathrm{C}=49.20 ; \mathrm{H}=5.69 ; \mathrm{N}=25.50$. Found: $C=49.20 ; H=5.54 ; N=25.41$. IR data $\left(v_{C \equiv N}, \mathrm{~cm}^{-1}\right)$ : 2115.1.

\section{Synthesis of compound 7}

The following $\left(1-2 \mathrm{H}^{+}\right) /\left(2-2 \mathrm{H}^{+}\right)$ratio was used: $1.0 \mathrm{mg} / 2.0 \mathrm{mg}$, (2.6*10-3 mmol / 5.2*10-3 mmol). Yield: $67 \%$.

Elemental analysis: calc. (\%) for $\left(\left[\mathrm{C}_{14} \mathrm{H}_{20} \mathrm{~N}_{4}\right]_{0.37}\left[\mathrm{C}_{14} \mathrm{H}_{20} \mathrm{~N}_{4}\right.\right.$ $\left.\left.\mathrm{O}_{2}\right]_{0.63}\right)_{3}\left[\mathrm{Fe}(\mathrm{CN})_{6}\right]^{3-2}$. $7.5 \quad \mathrm{H}_{2} \mathrm{O}: \mathrm{C}=47.95 ; \mathrm{H}=5.59 ; \mathrm{N}=24.85$. Found: $C=47.95 ; H=5.44 ; N=24.47$. IR data $\left(v_{C \equiv N}, \mathrm{~cm}^{-1}\right)$ : 2115.8.

Synthesis of compound $8\left(1-2 \mathrm{H}^{+}\right)_{3 x}\left(2-2 \mathrm{H}^{+}\right)_{3(1-x)}\left(\left[\mathrm{Fe}(\mathrm{CN})_{6}\right]^{3-}{ }_{2}\right)(\mathrm{x}=$ $0.37,0.53,0.67$ and 0.80$)$

The following $\left(1-2 \mathrm{H}^{+}\right) /\left(2-2 \mathrm{H}^{+}\right)$ratio was used: $0.5 \mathrm{mg} / 2.5 \mathrm{mg}$, (1.3*10-3 $\left.\mathrm{mmol} / 6.5^{*} 10^{-3} \mathrm{mmol}\right)$. Yield: $70 \%$.

Elemental analysis: calc. (\%) for $\left(\left[\mathrm{C}_{14} \mathrm{H}_{20} \mathrm{~N}_{4}\right]_{0.17}\left[\mathrm{C}_{14} \mathrm{H}_{20} \mathrm{~N}_{4}\right.\right.$ $\left.\left.\mathrm{O}_{2}\right]_{0.83}\right)_{3}\left[\mathrm{Fe}(\mathrm{CN})_{6}\right]^{3-}{ }_{2}$. $7.1 \mathrm{H}_{2} \mathrm{O}: \mathrm{C}=47.53 ; \mathrm{H}=5.48 ; \mathrm{N}=24.64$. Found: $C=47.55 ; H=5.31 ; N=24.43$. IR data $\left(v_{C \equiv N}, \mathrm{~cm}^{-1}\right)$ : 2114.3.

\section{Structural studies}

\section{Single-Crystal Studies}

Data were collected at $173(2) \mathrm{K}$ on a Bruker Apex-II-CCD Diffractometer equipped with an Oxford Cryosystem liquid $\mathrm{N}_{2}$ device, using graphite-monochromated Mo-K $\alpha$ ( $\lambda=0.71073 \AA$ ) radiation. For all structures, diffraction data were corrected for absorption. Structures were solved using SHELXS-97 and refined by full matrix least-squares on $F^{2}$ using SHELXL-97. The hydrogen atoms were introduced at calculated positions and refined using a riding model. ${ }^{24}$ In all cases, relative oxygen occupancies were refined around each $\left(2-2 \mathrm{H}^{+}\right)$cation. Structures can be obtained free of charge from the Cambridge
Crystallographic Data Centre via www.ccdc.cam.ac.uk/datarequest/cif. $\quad$ CCDC: 15501641550168.

\section{Powder diffraction studies (PXRD)}

Diagrams were collected on a Bruker D8 diffractometer using monochromatic $\mathrm{CU}-\mathrm{K}$ radiation with a scanning range between 4 and $40^{\circ}$ using a scan step size of $8^{\circ} / \mathrm{mn}$.

\section{Thermogravimetric (TGA) Studies}

TGA measurements have been performed on Pyris TGA4000 Lab System (Perkin-Elmer), using a $\mathrm{N}_{2}$ flow of $20 \mathrm{ml} / \mathrm{mn}$ and a heat rate of $10^{\circ} \mathrm{C} / \mathrm{mn}$

\section{Acknowledgements}

Financial supports from the University of Strasbourg, the International centre for Frontier Research in Chemistry (icFRC), the Labex CSC (ANR-10-LABX- 0026 CSC) within the Investissement d'Avenir program ANR-10-IDEX-0002-02, the Institut Universitaire de France, the CNRS, NSFC 21201049 and FFCSA-CSC are acknowledged.

\section{Notes and references}

1 a) A. I. Kitaigorodskii, Physical Chemistry, Vol. 29: Molecular Crystals and Molecules, Academic Press, New York, 1973; b) A. I. Kitaigorodsky, Mixed crystals, Vol. 33, Springer, Heidelberg, 1984.

2 G. A. Crundwell, B. A. Cowans, J. A. Hopkins, J. B. Grutzner, B. Kahr, J. Solid State Chem. 1999, 145, 327.

3 a) D. Braga, G. Cojazzi, D. Paolucci, F. Grepioni, Chem. Commun., 2001, 803; b) S. Ferlay, M. W. Hosseini, Chem. Commun., 2004, 787; c) K. Sada, K. Inoue, T. Tanaka, A. Epergyes, A. Tanaka, N. Tohnai, A. Matsumoto, M. Miyata, Angew. Chem. Int. Ed., 2005, 117, 7221; d) P. Dechambenoit, S. Ferlay, N. Kyritsakas, M. W. Hosseini, Chem. Commun., 2009, 1559.

4 a) C. S. Liang, W. T. A. Harrison, M. M. Eddy, T. E. Gier, G. D. Stucky, Chem. Mater., 1993, 5, 917; b) R. Shukla, J. Manjanna, A. K. Bera, S. M. Yusuf, A. K. Tyagi, Inorg. Chem., 2009, 48, 11691; c) P. Kanhere, J. Nisar, Y. Tang, B. Pathak, R. Ahuja, J. Zheng, Z. Chen, J. Phys. Chem. C, 2012, 116, 22767; d) D. Han, J. Cao, S. Yang, J. Yang, B. Wang, L. Fan, Q. Liu, T. Wang, H. Niu, Dalton Trans., 2014, 43, 11019; e) C. P. Heinrich, T. W. Day, W. G. Zeier, G. J. Snyder, W. Tremel, J. Am. Chem. Soc., 2014, 136, 442.

5 a) N. Korner, Ch. Pfammatter, R. Kind, Phys. Rev. Lett., 1993, 70, $1283 ;$ b) J. J. Fitzgerald, S. Prasad, J. Huang, J. S. Shore, J. Am. Chem. Soc., 2000, 122, 2556; c) I. Grinberg, M. R. Suchomel, W. Dmowski, S. E. Mason, H. Wu, P. K. Davies, A. M. Rappe1, Phys. Rev. Lett., 2007, 98, 107601; d) A. A. Bush, V. Ya. Shkuratov, K. E. Kamentsev, A. S. Prokhorov, E. S. Zhukova, B. P. Gorshunov, V. I. Torgashev, Phys. Rev. B, 2012, 85, 214112.

6 a) E. Flahaut, R. Bacsa, A. Peigney, C. Laurent, Chem. Commun., 2003, 1442; b) W.-T. Chen, K.-B. Chen, M.-F. Wang, S.-F. Weng, C.-S. Lee, M. 
C. Lin, Chem. Commun., 2010, 46, 3286; c) Z. Yi, J. Ye, N. Kikugawa, T. Kako, S. Ouyang, H. Stuart-Williams, H. Yang, J. Cao, W. Luo, Z. Li, Y. Liu, R. L. Withers, Nat. Mater., 2010, 9, 559; d) K. Kusada, H. Kobayashi, R. Ikeda, Y. Kubota, M. Takata, S. Toh, T. Yamamoto, S. Matsumura, N. Sumi, K. Sato, K. Nagaoka, H. Kitagawa, J. Am. Chem. Soc., 2014, 136, 1864; e) K. Sardar, E. Petrucco, C. I. Hiley, J. D. B. Sharman, P. P. Wells, A. E. Russell, R. J. Kashtiban, J. Sloan, R. I. Walton, Angew. Chem. Int. Ed., 2014, 53, 10960.

7 a) A. Widmann, H. Kahlert, I. Petrovic-Prelevic, H. Wulff, J. V. Yakhmi, N. Bagkar, F. Scholz, Inorg. Chem., 2002, 41, 5706; b) N. H. Babu, Y. Shi, K. lida, D. A. Cardwell, Nat. Mater., 2005, 4, 476; c) I. Willner, E. Katz, Langmuir, 2006, 22, 1409; d) G. Seber, R. S. Freitas, J. T. Mague, A. Paduan-Filho, X. Gratens, V. Bindilatti, N. F. Oliveira, Jr., N. Yoshioka, P. M. Lahti, J. Am. Chem. Soc., 2012, 134, 3825; e) C. Zhou, Z. Z. Fang, J. Lu, X. Zhang, J. Am. Chem. Soc., 2013, 135, 10982.

8 a) J. D. Dunitz, Chem. Commun., 2003, 545; b) J. D. Dunitz, A. Gavezzoti Angew. Chem. Int. Ed., 2005, 44, 1766.

9 a) Jones, J. T. A.; Hasell, T.; Wu, X.; Bacsa, J.; Jelfs, K. E.; Schmidtmann, M.; Chong, S. Y.; Adams, D. J.; Trewin, A.; Schiffman, F.; Cora, F.; Slater, B.; Steiner, A.; Day, G. M.; Cooper, A. I. Nature 2011, 474, 367;

10 a) S. Mann, Nature, 1993, 365, 499; b) M. Simard, D. Su, J. D. Wuest J. Am. Chem. Soc., 1991, 113, 4696; c) M. W. Hosseini, Acc. Chem. Res., 2005, 38, 313.

11 a) J. S. Lindsey, New J. Chem., 1991, 15, 153; b) J.-H. Fournier, T. Maris, J. D. Wuest, W. Guo, E. Galoppini, J. Am. Chem. Soc., 2003, 125, 1002; c) M. W. Hosseini, Coord. Chem. Rev., 2005, 240, 157; d) H. Jude, H. Disteldorf, S. Fischer, T. Wedge, A. M. Hawkridge, A. M. Arif, M. F. Hawthorne, D. C. Muddiman, P. J. Stang, J. Am. Chem. Soc., 2005, 127, 12131;

12 S. Ferlay and M. W. Hosseini, in "Functional supramolecular architectures for organic electronics and nanotechnology", ed. P. Samori and F. Cacialli, Wiley-VCH, 2010.

13 a) S. Ferlay, O. Félix, M. W. Hosseini, J.-M. Planeix, N. Kyritsakas, Chem. Comm., 2002, 702; b) S. Ferlay, V. Bulach, O. Félix, M. W. Hosseini, J.-M. Planeix, N. Kyritsakas, CrystEngComm, 2002, 4, 447; c) S. Ferlay, R. Holakovsky, M. W. Hosseini, J.-M. Planeix, N. Kyritsakas, Chem. Comm., 2003, 1224; d) P. Dechambenoit, S. Ferlay, M. W. Hosseini, J.-M. Planeix, N. Kyritsakas, New J. Chem., 2006, 30, 1403; e) P. Dechambenoit, S. Ferlay, M. W. Hosseini, N. Kyritsakas, Chem. Comm., 2007, 4626; f) P. Dechambenoit, S. Ferlay, M. W. Hosseini, N. Kyritsakas, Chem. Comm., 2009, 6798.
14 a) J. Fielden, D. L. Long, M. Speldrich, P. Kögerler, L. Cronin, Dalton Trans., 2012, 41, 4927; b) T. Yamada, Y. Shirai, H. Kitagawa, Chem. Asian J. 2014, 9, 1316.

15 a) N. B. Chanh, Y.Bouillard, P. Lencrerot, J. Chim. Phys., 1970, 67, 1206; b) M. Maroncelli, H. L. Strauss, R. G. Snyder, J. Phys. Chem., 1985, 89, 5260; c) D. L. Dorset, Proc. Natl. Acad. Sci. USA, 1990, 87, 8541; d) E. B. Sirota, H. E. Jr. King, H. H. Shao, D. M. Singer, J. Phys. Chem., 1995, 99, 798; e) D. Mondieig, P. Espeau, L. Robles, Y. Haget, H. A. J. Oonk, M. A. Cuevas-Diarte, J. Chem. Soc. Faraday Trans. 1997, 93, 3343;

16 a) C. B. Aakeröy, K. R. Seddon, Chem. Soc. Rev., 1993, 22, 397; b) S. Subramanian, M. J. Zaworotko, Coord. Chem. Rev., 1994, 137, 357; c) J. C. MacDonald, G. M. Whitesides, Chem. Rev., 1994, 94, 2383; d) G. R. Desiraju, Angew. Chem. Int. Ed., 1995, 34, 2311.

17 a) K. T. Holman, S. M. Martin, D. P. Parker, M. D. Ward, J. Am. Chem. Soc., 2001, 123, 4421; b) K. T. Holman, A. M. Pivovar, M. D. Ward, Science, 2001, 294, 1907; c) S. A. Dalrymple, G. K. H. Shimizu, J. Am. Chem. Soc., 2007, 129, 12114; d) M. J. Horner, K. T. Holman, M. D. Ward, J. Am. Chem. Soc. 2007, 129, 14640; e) M. W. Hosseini, Coord. Chem. Rev., 2003, 240, 157.

18 a) G. R. Desiraju, Angew. Chem. Int. Ed., 1995, 34, 2311; b) J. C. MacDonald, P. C. Dorrestein, M. M. Pilley, M. M. Foote, J. L. Lundburg, R. W. Henning, A. J. Schultz, J. L. Manson, J. Am. Chem. Soc., 2000, 112, 11692; c) K. Sada, K. Inoue, T. Tanaka, A. Epergyes, A. Tanaka, N. Tohnai, A. Matsumoto, M. Miyata, Angew. Chem. Int. Ed., 2005, 44, 7059; d) M. Dabros, P. R. Emery, V. R. Thalladi, Angew. Chem. Int. Ed., 2007, 46, 4132.

19 M. D. Ward, Organometallics, 1987, 6, 754.

20 a) R. D. Willett, R. E. Butcher, C. P. Landee, B. Twamley, Polyhedron 2006, 25, 2093; b) C. J. Adams, M. F. Haddow, M. Lusi, A. G. Orpen, Proc. Natl. Acad. Sci. USA, 2010, 107, 16033; c) C. J. Adams, A. L. Gillon, M. Lusi, A. G. Orpen, CrystEngComm, 2010, 12, 4403; d) E. Batisai, M. Lusi, T. Jacobs, L. J. Barbour, Chem. Commun., 2012, 48, 12171; e)M. Lusi, L.J. Barbour, Angew. Chem. Int. Ed. 2012, 51, 3928.

21 P. Dechambenoit, S. Ferlay, M. W. Hosseini, N. Kyritsakas, J. Am. Chem. Soc., 2008, 130,17106.

22 a)J. M. Lehn Chem. Eur. J. 1999, 5, 2455; b) D. S. Nesterov, V. N. Kokozay, J. Jezierska, O. V. Pavlyuk, R. Boca, A. J. L. Pombeiro Inorg. Chem. 2011, 50, 4401.

23 C. Horne "Geometric Symmetry in Patterns and Tilings" ed. Woodhead Publishing Series in Textiles, 2000.

24 Cerius2; Molecular Simulation Incorporated: San Diego, CA, 2001. 


\section{Journal Name}

\section{ARTICLE}

Table 3: Crystallographic data for structural analyses of $\left(1-2 \mathrm{H}^{+}\right)_{3 \times}\left(2-2 \mathrm{H}^{+}\right)_{3(1-x)}\left(\left[\mathrm{Fe}(\mathrm{CN})_{6}\right]_{2}\right)(0<\mathrm{x}<1) 4-8$, together with those of the already reported compounds $\mathbf{3}$ and $\mathbf{9} .{ }^{21}$

\begin{tabular}{|c|c|c|c|c|c|c|c|}
\hline \multirow[t]{2}{*}{ Phases } & \multicolumn{2}{|c|}{ A } & \multicolumn{3}{|c|}{ B } & \multicolumn{2}{|c|}{ C } \\
\hline & $3^{21}$ & 4 & 5 & 6 & 7 & 8 & $9^{21}$ \\
\hline Composition $\mathrm{x}$ & 1 & 0.80 & 0.67 & 0.53 & 0.37 & 0.17 & 0 \\
\hline Formula & $\begin{array}{c}{[1-} \\
\left.2 \mathrm{H}^{+}\right]_{3}\left[\mathrm{Fe}^{\text {"III }}(\mathrm{CN})_{6}\right]_{2} \\
.7 \mathrm{H}_{2} \mathrm{O} \\
\end{array}$ & $\begin{array}{c}\left(\left[\mathbf{1}-2 \mathrm{H}^{+}\right]_{0.80}[\mathbf{2 -}\right. \\
\left.\left.2 \mathrm{H}^{+}\right]_{0.20}\right)_{3}\left[\mathrm{Fe}^{\prime \prime \prime}(\mathrm{C}\right. \\
\left.\mathrm{N})_{6}\right]_{2 .} .7 \mathrm{H}_{2} \mathrm{O} \\
\end{array}$ & $\begin{array}{c}\left(\left[\mathbf{1 - 2 \mathrm { H } ^ { + }}\right]_{0.67}[\mathbf{2 -}\right. \\
\left.\left.2 \mathrm{H}^{+}\right]_{0.33}\right)_{3}\left[\mathrm{Fe}^{\prime \prime \prime}(\mathrm{C}\right. \\
\left.\mathrm{N})_{6}\right]_{2 .} 8 \mathrm{H}_{2} \mathrm{O} \\
\end{array}$ & $\begin{array}{c}\left(\left[\mathbf{1}-2 \mathrm{H}^{+}\right]_{0.53}[\mathbf{2}-\right. \\
\left.\left.2 \mathrm{H}^{+}\right]_{0.47}\right)_{3}\left[\mathrm{Fe}^{\prime \prime \prime}(\mathrm{C}\right. \\
\left.\mathrm{N})_{6}\right]_{2 .} 8 \mathrm{H}_{2} \mathrm{O} \\
\end{array}$ & $\begin{array}{c}\left(\left[\mathbf{1}-2 \mathrm{H}^{+}\right]_{0.37}[\mathbf{2}-\right. \\
\left.\left.2 \mathrm{H}^{+}\right]_{0.63}\right)_{3}\left[\mathrm{Fe}^{\prime \prime \prime}(\mathrm{C}\right. \\
\left.\mathrm{N})_{6}\right]_{2 .} 8 \mathrm{H}_{2} \mathrm{O} \\
\end{array}$ & $\begin{array}{c}\left(\left[\mathbf{1}-2 \mathrm{H}^{+}\right]_{0.17}[\mathbf{2 -}\right. \\
\left.\left.2 \mathrm{H}^{+}\right]_{0.83}\right)_{3}\left[\mathrm{Fe}^{\prime \prime \prime}(\mathrm{C}\right. \\
\left.\mathrm{N})_{6}\right]_{2 .} 8 \mathrm{H}_{2} \mathrm{O} \\
\end{array}$ & $\begin{array}{c}\mathbf{2 -} \\
\left.2 \mathrm{H}^{+}\right]_{3}\left[\mathrm{Fe}^{\prime \prime \prime}(\mathrm{CN})_{6}\right]_{2} \\
.8 \mathrm{H}_{2} \mathrm{O} \\
\end{array}$ \\
\hline $\begin{array}{c}\text { Molecular } \\
\text { weight }\end{array}$ & 1283.07 & 1299.07 & 1333.08 & 1345.88 & 1361.89 & 1381.08 & 1397.09 \\
\hline Crystal System & Triclinic & Triclinic & Monoclinic & Monoclinic & Monoclinic & Monoclinic & Monoclinic \\
\hline Space Group & $\mathrm{P} \overline{1}$ & $\mathrm{P} \overline{1}$ & $\mathrm{P} 2_{1} / \mathrm{n}$ & $\mathrm{P} 2_{1} / \mathrm{n}$ & $\mathrm{P} 2_{1} / \mathrm{n}$ & $\mathrm{P} 2_{1} / \mathrm{n}$ & $\mathrm{P} 2_{1} / \mathrm{n}$ \\
\hline a $(\AA ̊)$ & $7.0949(3)$ & $7.0769(8)$ & $7.0846(5)$ & $7.06960(10)$ & $7.08870(10)$ & $7.1019(3)$ & $7.0978(5)$ \\
\hline$b(\AA ̊)$ & $12.3765(5)$ & $12.5517(14)$ & $35.531(2)$ & $35.4378(7)$ & $35.4699(7)$ & $22.0731(10)$ & $22.2254(16)$ \\
\hline$c(\AA ̊)$ & $17.9534(7)$ & $17.9244(18)$ & $12.6872(8)$ & $12.7602(3)$ & $12.8214(2)$ & $20.6168(10)$ & $20.6357(12)$ \\
\hline$\alpha\left(^{\circ}\right)$ & $83.580(2)$ & $82.908(5)$ & 90 & 90 & 90 & 90 & 90 \\
\hline$\beta\left(^{\circ}\right)$ & $87.6101(10)$ & $87.892(5)$ & $94.818(2)$ & $94.7890(10)$ & $94.7200(10)$ & $92.0750(10)$ & $92.363(3)$ \\
\hline$\gamma\left(\left(^{\circ}\right)\right.$ & $83.9340(10)$ & $84.717(5)$ & 90 & 90 & 90 & 90 & 90 \\
\hline$\vee\left(\AA^{3}\right)$ & 1557.12(11) & $1572.8(3)$ & $3182.4(4)$ & $3185.67(11)$ & $3212.82(9)$ & $3229.8(3)$ & $3252.5(4)$ \\
\hline $\mathrm{z}$ & 1 & 1 & 4 & 4 & 4 & 2 & 2 \\
\hline Colour & Light green & Light green & Light green & Light green & Light green & Light green & Light green \\
\hline $\begin{array}{l}\text { Crystal dim } \\
\left(\mathrm{mm}^{3}\right)\end{array}$ & $0.1 \times 0.06 \times 0.05$ & $0.04 \times 0.04 \times 0.05$ & $0.05 \times 0.05 \times 0.06$ & $0.04 \times 0.04 \times 0.05$ & $0.05 \times 0.06 \times 0.06$ & $0.04 \times 0.05 \times 0.05$ & $0.05 \times 0.04 \times 0.02$ \\
\hline $\mathrm{D}\left(\mathrm{g} / \mathrm{cm}^{3}\right)$ & 1.368 & 1.372 & 1.391 & 1.395 & 1.411 & 1.420 & 1.428 \\
\hline$F(000)$ & 674 & 682 & 1400 & 1396 & 1432 & 1448 & 1304 \\
\hline$\mu\left(m m^{-1}\right)$ & 0.536 & 0.533 & 0.531 & 0.531 & 0.530 & 0.529 & 0.527 \\
\hline Wavelength (Å) & 0.71073 & 0.71073 & 0.71073 & 0.71073 & 0.71073 & 0.71073 & 0.71073 \\
\hline $\begin{array}{c}\text { Number of data } \\
\text { meas. }\end{array}$ & 22955 & 17456 & 16842 & 35778 & 33286 & 21745 & 13916 \\
\hline $\begin{array}{l}\text { Number of data } \\
\text { with } 1>2 \sigma(I)\end{array}$ & 9536 & $\begin{array}{c}7323[\mathrm{R} \text { (int) }= \\
0.0682]\end{array}$ & $\begin{array}{c}5524[R(\text { int })= \\
0.0347]\end{array}$ & $\begin{array}{c}8993[R \text { (int) }= \\
0.0297]\end{array}$ & $\begin{array}{c}9245[R \text { (int) }= \\
0.0302]\end{array}$ & $\begin{array}{c}5689[\mathrm{R} \text { (int) }= \\
0.0290]\end{array}$ & 6294 \\
\hline $\mathrm{R}$ & $\begin{aligned} R 1 & =0.0588 \\
w R 2 & =0.0814\end{aligned}$ & $\begin{array}{l}R 1=0.0864 \\
w R 2=0.2133\end{array}$ & $\begin{aligned} R 1 & =0.0469 \\
w R 2 & =0.1135\end{aligned}$ & $\begin{array}{l}R 1=0.0530 \\
w R 2=0.1381\end{array}$ & $\begin{array}{r}R 1=0.0485 \\
w R 2=0.1179\end{array}$ & $\begin{array}{r}\mathrm{R} 1=0.0546 \\
\mathrm{wR2}=0.1362\end{array}$ & $\begin{array}{l}R 1=0.1084 \\
w R 2=0.3045\end{array}$ \\
\hline Rw & $\begin{aligned} R 1 & =0.1540 \\
w R 2 & =0.1728\end{aligned}$ & $\begin{array}{c}R 1=0.1227 \\
W R 2=0.2351\end{array}$ & $\begin{aligned} R 1 & =0.0554 \\
w R 2 & =0.1191\end{aligned}$ & $\begin{array}{l}R 1=0.0625 \\
W R 2=0.1443\end{array}$ & $\begin{array}{c}R 1=0.0595 \\
w R 2=0.1237\end{array}$ & $\begin{array}{c}R 1=0.0599 \\
W R 2=0.1404\end{array}$ & $\begin{array}{c}R 1=0.2008 \\
w R 2=0.2797\end{array}$ \\
\hline GOF & 1.087 & 1.005 & 1.045 & 1.022 & 1.078 & 1.038 & 1.055 \\
\hline $\begin{array}{l}\text { Largest peak in } \\
\text { final difference } \\
\left(\mathrm{e}^{-3}\right)\end{array}$ & $\begin{array}{c}0.789 \text { and - } \\
0.468\end{array}$ & $\begin{array}{c}1.426 \text { and - } \\
0.551\end{array}$ & $\begin{array}{c}0.722 \text { and - } \\
0.445\end{array}$ & $\begin{array}{c}0.883 \text { and - } \\
0.468\end{array}$ & $\begin{array}{l}0.736 \text { and - } \\
0.446\end{array}$ & $\begin{array}{c}1.383 \text { and - } \\
1.390\end{array}$ & $\begin{array}{c}0.476 \text { and - } \\
0.806\end{array}$ \\
\hline
\end{tabular}

${ }^{\mathrm{a}} R=\Sigma\left(|| F_{\mathrm{o}}|-| F_{\mathrm{c}}||\right) / \Sigma\left|F_{\mathrm{o}}\right| ;{ }^{b} W R=\left[\Sigma\left[w\left(F_{\mathrm{o}}^{2}-F_{\mathrm{c}}^{2}\right)^{2}\right] / \Sigma w\left(F_{\mathrm{o}}^{2}\right)^{2}\right]^{1 / 2}$. 


\section{Graphical Abstract}

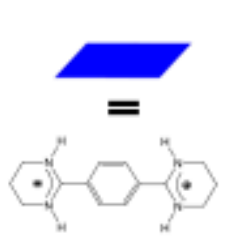

$\left(\mathbf{1} \cdot 2 \mathrm{H}^{+}\right)$

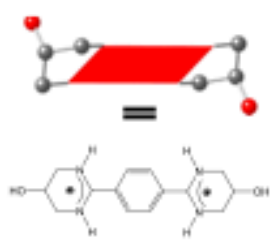

$\left(2 \cdot 2 \mathrm{H}^{+}\right)$
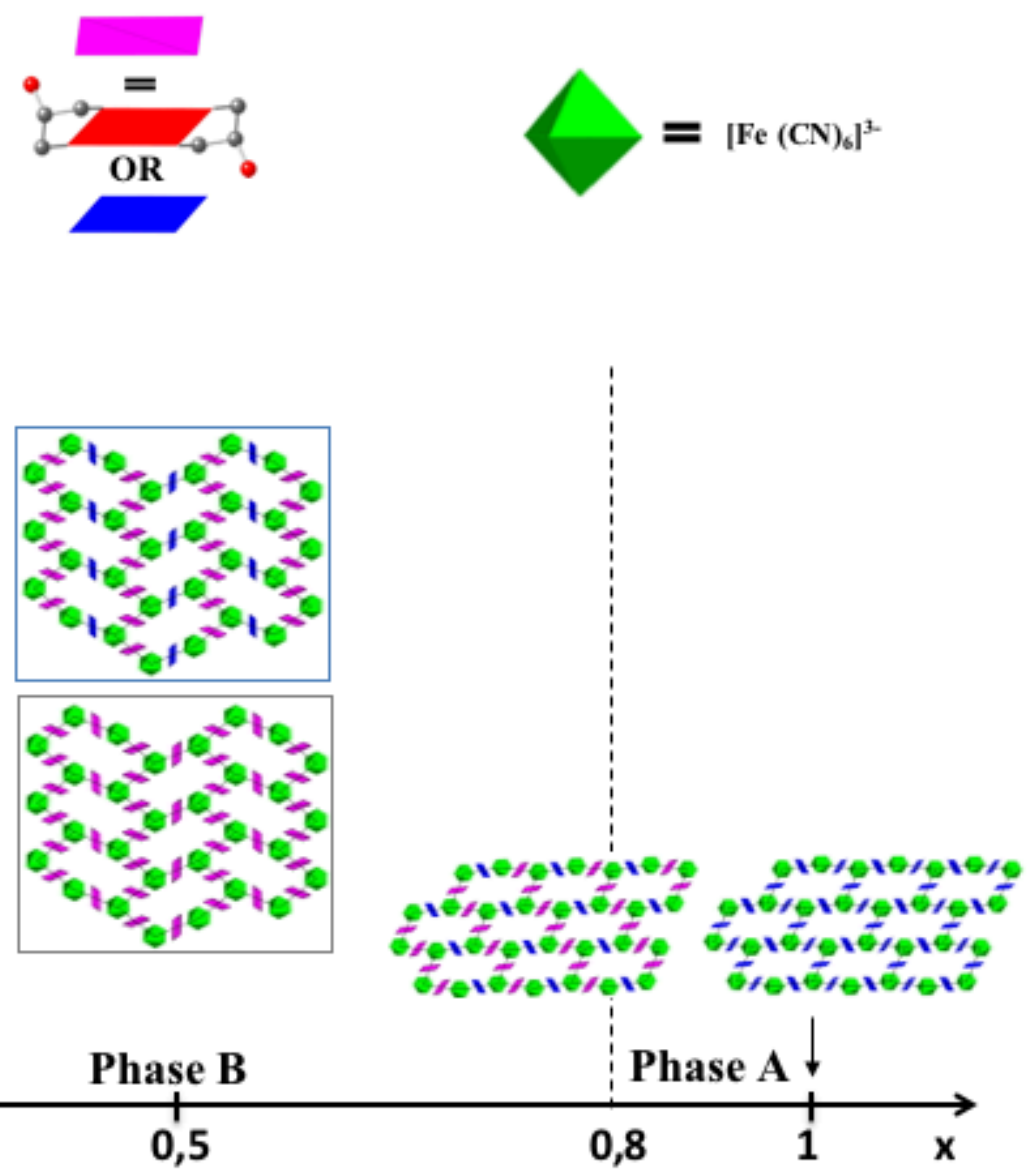

$\left(1-2 \mathrm{H}^{+}\right)_{3 \mathrm{x}}\left(2-2 \mathrm{H}^{+}\right)_{3(1-\mathrm{x})}\left(\left[\mathrm{Fe}(\mathrm{CN})_{6}\right]^{3-}{ }_{2}\right) \cdot \mathrm{n} \mathrm{H}_{2} \mathrm{O}$ 